Trade-offs between economic returns, biodiversity, and ecosystem services in the selection of energy peat production sites

\author{
Juutinen, Artti
}

$2019-12$

Juutinen , A, Saarimaa , M , Ojanen , P , Sarkkola , S, Haara , A , Karhu , J , Nieminen , M , Minkkinen , K , Penttila , T , Laatikainen, M \& Tolvanen , A 2019 , ' Trade-offs between economic returns, biodiversity, and ecosystem services in the selection of energy peat production sites ' , Ecosystem Services , vol. 40 , 101027 . https://doi.org/10.1016/j.ecoser.2019.101027

http://hdl.handle.net/10138/336309

https://doi.org/10.1016/j.ecoser.2019.101027

cc_by_nc_nd

acceptedVersion

Downloaded from Helda, University of Helsinki institutional repository.

This is an electronic reprint of the original article.

This reprint may differ from the original in pagination and typographic detail.

Please cite the original version. 


\title{
Trade-offs between economic returns, biodiversity, and ecosystem services in the selection of energy peat production sites
}

\author{
Artti Juutinen $^{\mathrm{a}, \mathrm{b}, *}$, Miia Saarimaa ${ }^{\mathrm{a}}$, Paavo Ojanen ${ }^{\mathrm{c}}$, Sakari Sarkkola ${ }^{\mathrm{d}}$, Arto Haara ${ }^{\mathrm{e}}$, Jouni Karhu ${ }^{\mathrm{a}}$, \\ Mika Nieminen $^{\mathrm{d}}$, Kari Minkkinen ${ }^{\mathrm{c}}$, Timo Penttilä ${ }^{\mathrm{d}}$, Matti Laatikainen ${ }^{\mathrm{f}}$, Anne Tolvanen ${ }^{\mathrm{a}}$

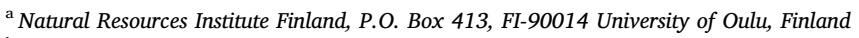 \\ ${ }^{\mathrm{b}}$ Department of Economics, P.O. Box 8000, FI-90014 University of Oulu, Finland \\ ${ }^{\mathrm{c}}$ University of Helsinki, Department of Forest Sciences, P.O. Box 27, FI-00014 Helsinki, Finland \\ ${ }^{\mathrm{d}}$ Natural Resources Institute Finland, Latokartanonkaari 9, FI-00790 Helsinki, Finland \\ ${ }^{\mathrm{e}}$ Natural Resources Institute Finland, Yliopistokatu 6, FI-80100 Joensuu, Finland \\ ${ }^{\mathrm{f}}$ Geological Survey of Finland, P.O. Box 96, FI-70211 Kuopio, Finland
}

\section{A R T I C L E I N F O}

\section{Keywords:}

Biodiversity

Ecosystem services

GHG emissions

Multi-objective optimization

Peatlands

Water quality

\begin{abstract}
A B S T R A C T
Economic development creates challenges for land-use planners in balancing between increasing the use of natural resources and safeguarding biodiversity and ecosystem services. We developed and utilized multi-objective numeric optimization models to analyze the trade-offs between biodiversity and ecosystem services (BES). The approach was used in the land-use planning process in northern Finland when selecting potential peat production sites as a part of the development of the regional master plan. We first quantified Net Present Value (NPV) of peat production, biodiversity, greenhouse gas (GHG) emissions, and water emissions of peatlands. Then we applied multi-objective optimization to examine the trade-offs between the variables as well as to determine a cost-efficient selection of potential peat production sites, that is, a selection which would simultaneously generate the greatest possible economic returns and environmental benefits. Our results showed that with a relatively small decrease in NPV, a substantial decrease in biodiversity loss and a reduction in water emissions compared to the benchmark level could be attained. However, a significant decrease in GHG emissions resulted in a substantial decrease in NPV. We conclude that it is possible to significantly improve land-use management by applying multi-objective optimization in land-use planning.
\end{abstract}

\section{Introduction}

Economic development creates challenges for land users and policy makers in balancing between increasing the use of natural resources and safeguarding biodiversity and ecosystem services (BES) (Millennium Ecosystem Assessment, 2005). This means that trade-offs are inevitable, and compromises are needed when multiple, often controversial, objectives are taken into account in land-use planning and decision making. Instead of concentrating on direct economic returns obtained from nature, the aim should be multi-functional landscape that simultaneously generates ecological, social, and economic benefits. Alternative strategies exist for supporting multi-functional land-uses including land-sparing, land-sharing and mixed strategies (Law et al., 2017). Since the effects of these strategies vary across heterogeneous landscapes, a thorough analysis of the impacts of alternative land-uses is needed to identify the cost-effective strategy for land-use planning.

Trade-offs occur when one ecosystem service is enhanced at the expense of another. If trade-offs are not acknowledged and identified within a thorough analysis, no response policy may be particularly efficient in managing ecosystem services in a sustainable way (Inostroza et al., 2017). Considerable trade-offs occur particularly in the use of peatlands, which are widely utilized peat-forming wetland ecosystems throughout the world. Peatlands provide habitats for many species and they also provide a variety of ecosystem services such as peat and timber production, carbon sequestration, and recreational benefits (e.g., Zedler and Kercher, 2005). Due to intensive use of peatlands in Europe (Joosten and Clarke, 2002; Chapman et al., 2003), any further deprivation should be well justified.

The most intensive peatland use is energy peat production, practiced especially in countries rich in peatlands, such as Belarus, Estonia, Finland, Indonesia, Ireland, the Russian Federation, and Sweden.

\footnotetext{
* Corresponding author at: Natural Resources Institute Finland, P.O. Box 413, FI-90014 University of Oulu, Finland.

E-mail address: artti.juutinen@luke.fi (A. Juutinen).
} 
Finland constitutes $59 \%$ of the annual energy peat use in the EU (World Energy Council, 2013). In 2014, a total of 69,000 ha, around $0.8 \%$ of the total peatland area, was under peat production for energy, horticultural, and other uses in Finland (Finnish Statistical Yearbook of Forestry, 2014). Energy peat is mostly produced by large companies, such as Vapo (https://www.vapo.com/en). Despite plans to reduce the use of energy peat by 2025 (Ministry of Economic Affairs and Employment of Finland, 2013), replacing peat with woodchips or other renewable resources takes time. Thus, new energy peat production sites are still being established.

This study focuses on the tradeoffs between BES in the selection of potential energy peat production sites at a regional level. The study presents a real-world decision-making problem associated with the land-use planning, since it was integrated in updating a regional master plan in northern Finland (Council of Oulu Region, 2018). In Finland, regional councils are responsible for drawing up regional master plans, which set out a framework for all local land-use planning. The Finnish Government Program on the sustainable use of mires and peatlands (Ministry of Agriculture and Forestry, 2012) states that all actions that considerably change the function of peatlands, such as peat production, should be allocated to drained or otherwise degraded peatlands. Hence, in regional land-use planning process the suitability of areas for peat production needs to be considered to reconcile both peat production and conservation needs. This means careful evaluation of trade-offs. The study utilizes iterative stakeholder engagement to take into account the needs of the regional planner, as well as to enable a more informed dialogue (Rosenthal et al., 2014). In general, spatial planners can be seen as the key players in finding solutions to alleviate trade-offs caused by alternative land-use or management choices (Turkelboom et al., 2018).

Various methods have been developed and utilized for the evaluation of trade-offs between BES as shown in the reviews by Seppelt et al. (2013), Deng et al. (2016), and Ochoa and Urbina-Cardona (2017). Also recent special issue edited by Inostroza et al. (2017) provides a broad view on integrated approaches to evaluate trade-offs between BES (Grêt-Regamey et al., 2017; Shoyama et al., 2017; Sun et al., 2017) or between ecosystem services (Hermanns et al., 2017; Sherrouse et al., 2017; Trodahl et al., 2017).

In general GIS-based assessments (Maes et al., 2012) and multicriteria methods (Haara et al., 2018) have been shown to effectively reveal trade-offs between multiple targets at varying temporal and spatial scales. Ecosystem services are spatial by nature (e.g., Potschin \& Haines-Young, 2011, Schröter et al., 2015), their spatial mapping is important (Hauck et al., 2013), but methods to choose the best land-use solutions under given levels of ecosystem services are also needed. Scenario analysis is the most frequently used tool for assessing land-use options and characterizing possible future scenarios (Seppelt et al., 2013). The analysis provides information on the contribution of certain types of land-use to selected ecosystem services and monetary values. Optimization can be used to identify efficient land-use solutions under given constraints and social preferences or values (Nelson et al., 2008; Polasky et al., 2008; Armsworth et al., 2012; Kennedy et al., 2016; Pennington et al., 2017). Still, quantification of the non-linear relationship between ecosystem services and land-use remains a challenge for sustainable land-use (Deng et al., 2016). Non-linear relationships indicates that there may be many land-use options with small losses in satisfying immediate human needs but large gains in maintaining ecosystems (De Fries et al., 2004).

Previous studies on the use of peatlands have mainly focused on peatland conservation and restoration (e.g., Evans et al., 2014; Glenk et al., 2014; Martin-Ortega et al., 2014; Albrecht and Ratamäki, 2016). A few approaches have also been used to locate suitable peat production sites in the practical planning process. For example, methods based on classification and exclusion of peatlands based on some predetermined factors, such as proximity to nature conservation areas or settlements, and environmental and social impacts with respect to watercourses have been applied (Onkila et al., 2012; Compton et al., 2013). Classification criteria can be exclusionary or advisory depending on the goals of decision makers and preferences of stakeholders. Additionally, inverse spatial conservation prioritization was developed for land-use zoning at the landscape scale to avoid negative ecological effects of peat production by identifying areas with the highest economic but lowest ecological value (Kareksela et al., 2013).

Glenk et al. (2014) propose a Cost-Benefit Analysis (CBA), including the valuation of ecosystem services, for targeting areas for peatland restoration. From an economic point of view, CBA is an ideal approach in the sense that it produces a socially optimum solution (i.e., the greatest welfare gains to society). CBA is also suitable for targeting areas for energy peat production. The valuation of non-market benefits provided by peatlands involves, however, many challenges, such as incomplete information on the impacts, and spatial and temporal differences in peatlands' responses to management (e.g., Martin-Ortega et al., 2014). Therefore, we quantify ecosystem service delivery but do not place monetary values on non-market benefits.

Our contribution to ecosystem service literature consists of a comprehensive quantitative approach which is directly incorporated into a practical decision-making process. We (i) integrate and elaborate existing economic and environmental data to quantify and valuate the economic returns and BES of peatlands, (ii) search for the cost-efficient selection of potential peat production sites which simultaneously generate the highest economic returns and BES possible, and (iii) examine trade-offs between economic returns and BES to assist land-use planning in the selection of potential peat production sites as a part of a regional planning process in northern Finland. Based on our discussions with the regional council we use four target variables in the analysis: NPV of peat production, biodiversity, GHG emissions, and environmental loading to watercourses. The variables are quantified by taking into account their long term development and utilizing available highresolution environmental data in spatial format.

\section{Methods and material}

\subsection{Study area}

Our study area is the Vaala municipality in northern Finland (Fig. 1) covering an area of $1759 \mathrm{~km}^{2}$, of which ca. $750 \mathrm{~km}^{2}$ are classified as peatlands based on Multi-Source Forest Inventory (MS-NFI) data (Natural Resources Institute Finland, 2018; Mäkisara et al., 2016). The area represents a typical boreal landscape with a mosaic of mineral soil forests, peatlands, lakes, and farmlands. The Vaala municipality has a low population density (ca. 3000 inhabitants with 2.3 persons per $\mathrm{km}^{2}$ ) and it represents a typical northern Finnish rural area with a narrow economic structure and high unemployment rate (ca. 18\%). A regional master plan, which guides the land-use allocation, was updated by the Council of Oulu Region for the Vaala municipality in 2018. Potential peat production sites had to be assigned as part of the plan, and since energy peat production is highly regulated in Finland, its potential economic, environmental, and social impacts had to be considered. Our results were incorporated into this planning process through continuous interaction with the Council of Oulu Region.

There was a quantitative target to assign approximately 2000 ha as potential peat production sites in the plan. Based on previous experience of the Council of Oulu Region the assigned area was about 2-3 times larger than would be the actual peat production area. This was because the private peat production enterprises would eventually not be able to utilize all potential sites due to their low economic profitability or because of the resistance by local people due to potential negative environmental impacts.

\subsection{Decision criteria and land-use options}

We pre-selected potential peat production sites using five exclusive 


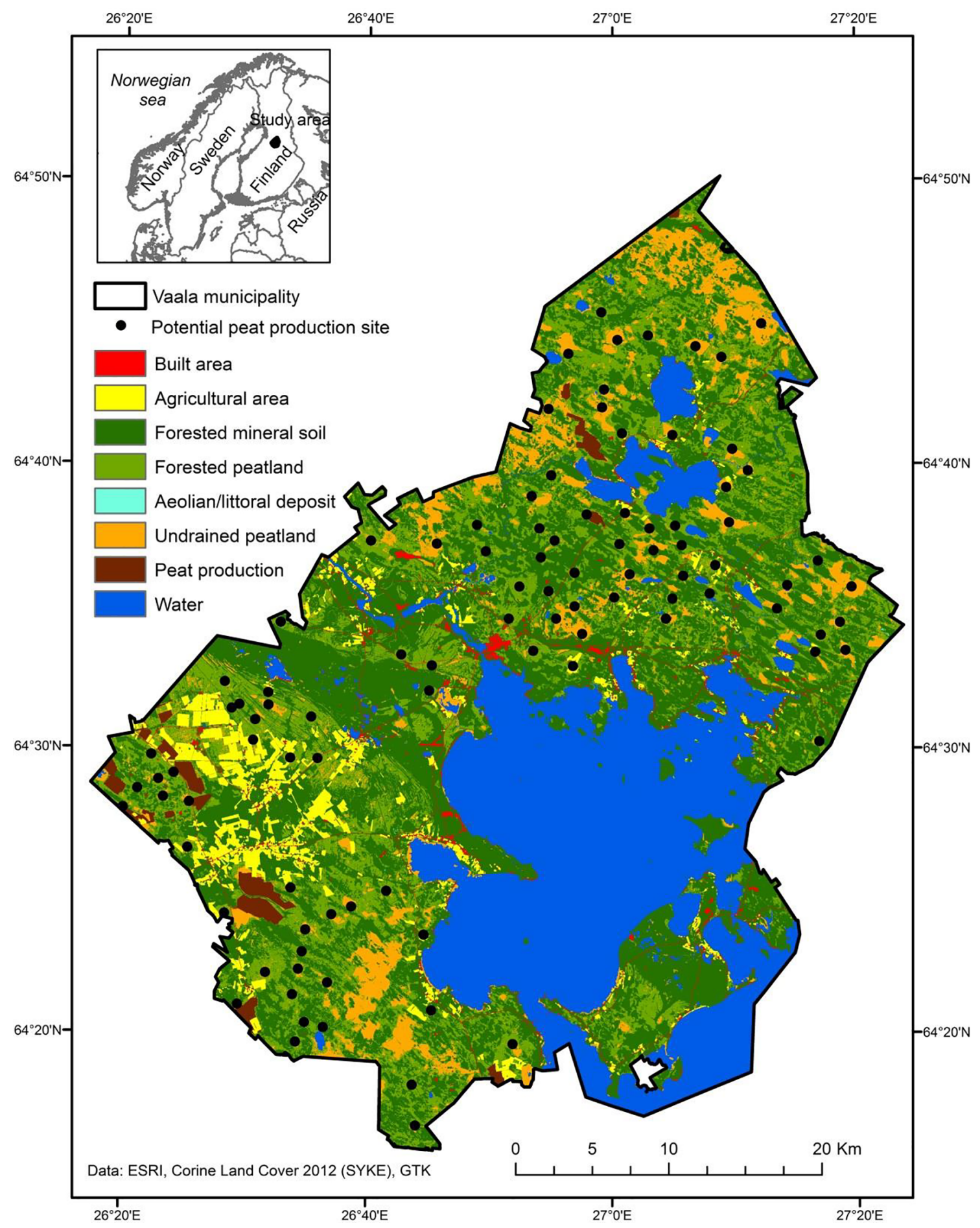

Fig. 1. Study area.

criteria that were defined by the Council of Oulu Region. The first two criteria were the average thickness of peat deposits ( $\geq 1.5$ meters) and the size of the peatland site ( $\geq 10 \mathrm{ha}$ ), which aim to rule out sites with too low economic potential. These criteria were fulfilled by 103 peatland sites. The other three criteria were the distance to the nearest settlement ( $\geq 0.5$ kilometers), the nearest nature protection area $(\geq 0.5$ kilometers), and the nearest groundwater discharge area reserved for drinking water supply ( $\geq 0.5$ kilometers). The final data included 99 peatland sites.
NPV of peat production, biodiversity, GHG emissions, and environmental loading to watercourses were quantified for each potential peatland site. Under peat production, all peat soil is removed from a site, that is, the original habitat is permanently converted to another type of habitat. Therefore, the biodiversity value was calculated for the present state and that value was assumed to be lost in the case of peat production. The values for GHG emissions and environmental loading to watercourses were calculated as a difference between the two management options: the peat production option and the current land- 
use option (i.e. business as usual), acknowledging that the current landuse also causes environmental impacts.

The current land-use was set according to the site data from the MSNFI (Natural Resources Institute Finland, 2018) data and Corine Land Cover Classification (CLC2012, Finnish Environment Institute, 2018). In the current land-use option, forestry and agriculture were assumed to continue at those parts of the sites that were classified as forestrydrained or agricultural peatlands at the time of the study. Effects of forest growth and cuttings were predicted using the large-scale forest planning system MELA (Redsven et al., 2013) and growing stock and site data from MS-NFI (Natural Resources Institute Finland, 2018). Those parts of the sites that were classified as undrained peatlands were assumed to remain undrained in the simulation of the effects of the current land-use option.

Peat production and the associated impacts on GHG and watercourses occur over a long time period. Therefore, the values for these two environmental variables were assessed as cumulative values during the peat production period, usually $30-40$ years. In the simulation of the peat production option, we made an assumption that all peat areas (undrained, forestry-drained, agriculture-drained) within the study sites would be brought into peat production.

Land-use planning requires detailed spatial information on the heterogeneity of the target areas. To this end, several sources of data were used to pre-select potential peat production sites, to assess their present status, and to quantify and valuate their biodiversity and ecosystem services (Table 1). For example, peatland mapping data were used to calculate NPV of peat production, whereas high-resolution MSNFI data were used to identify the properties of sites in terms of their impacts on biodiversity, GHG emissions and environmental loading to watercourses.

\subsection{NPV of peat production}

NPV of peat production was calculated to measure the profitability of the potential peat production sites. For that purpose, all associated revenues and costs were assessed. The costs included the costs of establishing the production site $\left(€ 9000 \mathrm{ha}^{-1}\right)$, the costs of peat extraction $(€ 8.08$ $\mathrm{MWh}^{-1}$ ), as well as those of haulage $\left(€ 2.8 \mathrm{MWh}^{-1}\right)$. The costs were estimated based on information provided by Vapo, the largest Finnish peat production company (personal communication). Peat production companies typically rent production sites from landowners, but land renting was not included in the costs of peat production. From the viewpoint of social planner, land rents are income transfers from peat production companies to landowners, thus having no effect on net benefits.

It takes several years to prepare a peatland site for peat production, that is, to harvest the tree stand and stumps, excavate drainage and main outflow ditches, construct roads, etc. We divided the costs of preparation equally for the first three years, after which peat production was assumed to start. Annual peat production was estimated to be $450 \mathrm{~m}^{3} \mathrm{ha}^{-1} \mathrm{yr}^{-1}$, which represents the past long-term average production in Finland (Vapo, personal communication; Flyktman, 2005). The production time for each site was calculated by dividing the total volume of peat by the annual peat production estimate.

The annual revenues were calculated by multiplying the annual peat production by the peat price. The peat price was $€ 13.1 \mathrm{MWh}^{-1}$, which equals the average milled peat price for 2011-2015 (Statistics Finland, 2018; Table 1) adjusted by the producer price index. Finally, NPV was calculated with a $3 \%$ discount rate for all potential peat production sites. The NPV figures should be considered as rough estimates. In practice, NPV depends on several site-specific factors that we were not able to take into account.

\subsection{Biodiversity value}

The conservation of the biodiversity of peatlands is regulated in Finland. In addition to the conservation areas under the Nature
Conservation Act, sufficient attention must be paid to the general importance of all other natural peatland habitats for biodiversity and the preservation of landscape values. ${ }^{1}$

The present biodiversity value of the potential peat production sites was assessed by applying the guidelines given by the Ministry of the Environment concerning the sustainable use of mires and peatlands in land-use planning (Ympäristöministeriö, 2015). It was estimated on the basis of six criteria that are expected to capture the most important determinants of biodiversity values of peatlands: habitat types (mire site types, water formations), mire complex types (Cajander, 1913) and geomorphological formations, presence of threatened plant and bird species, habitat connectivity, undrained peatland area coverage, and habitat suitability predictions for eight threatened plant species (for data, see Table 1). The biodiversity value, denoted hereafter as Biodiversity loss, of each peatland site was finally calculated as the weighted sum of the criteria-specific scores (for details of the calculations, see Supplement 1). The values varied from 0.85 to 3.05 with a mean of 1.39. Biodiversity loss should be interpreted as a relative index with higher values indicating more suitable sites for biodiversity conservation.

\subsection{GHG emissions}

GHG $\left(\mathrm{CO}_{2}, \mathrm{CH}_{4}, \mathrm{~N}_{2} \mathrm{O}\right)$ emissions of potential peat production sites were calculated as the difference between the total GHG emissions ( $\mathrm{Mg}$ $\mathrm{CO}_{2}$ equivalents, GWP100) for the peat production option and the current land-use option until the end of the peat production. First, annual GHG emissions and removals were estimated by multiplying the emission factors (Table 1, Table S21) by the size of the respective peatland site or the peat energy content. Second, annual emissions of each gas were summed for both land-use options to estimate the total emissions during the time period of peat production. Third, the total emissions of different gases were converted to $\mathrm{CO}_{2}$ equivalents by multiplying them by their respective global warming potentials for a 100-year time interval (Myhre et al., 2013). For the peat production option, emissions from cutting of the tree stand prior to peat production, the burning of peat, as well as the soil emissions from the production area were included. For the current land-use option, soil emissions from undrained peatlands and peatlands drained for forestry and agriculture were included (for details of the calculations, see Supplement 2).

\subsection{Environmental loading to watercourses}

Water quality impacts caused by land-use activities were calculated for the total nitrogen (TN), total phosphorus (TP), and total organic carbon (TOC), which are among of the most important water quality parameters contributing to water eutrophication and brownification (Schindler, 1998; Williamson et al., 2015). For the peat production option, the exports induced by the preparation of the peat field for peat production and the following production phases were included. The net exports from undrained peatland sites were assumed to be zero.

The TN, TP, and TOC exports from agriculture were derived from the literature (Table S31), and the exports caused by peat production and forestry were calculated using the runoff and the so-called specific concentrations (Palviainen et al., 2015). For this, we first estimated the

\footnotetext{
${ }^{1}$ Environmental Impact Assessment (EIA) concerns peat production areas more than 150 hectares. In the EIA process, the impact of the project to environment is assessed at the preparation stage before any decisions are made and when the forthcoming solutions may still be influenced. The EIA process is a project planning tool, and its results must be taken into account when granting permits for projects. See" https://www.ymparisto.fi/fi-FI/Asiointi_ luvat_ja_ymparistovaikutusten_arviointi/Ymparistovaikutusten_arviointi" for further information.
} 
Table 1

Data used to pre-select and quantify and valuate the biodiversity and ecosystem services of potential peat production sites.

\begin{tabular}{|c|c|}
\hline Data & Source \\
\hline Size (ha), peat volume $\left(\mathrm{m}^{3}\right)$, and the energy content of peat (MWh) & Geological Survey of Finland $2011^{*}, 2016^{* *}$ \\
\hline Land-use type (forestry/agriculture), resolution $20 \mathrm{~m} \times 20 \mathrm{~m}$ & $\begin{array}{l}\text { Corine Land Cover Classification (CLC2012), Finnish Environment Institute (2018), Härmä } \\
\text { et al. (2013) }\end{array}$ \\
\hline Stand volumes $\left(\mathrm{m}^{3} \mathrm{ha}^{-1}\right)$ and carbon storage of tree biomass $\left(\mathrm{kg} \mathrm{ha}^{-1}\right)$ & $\begin{array}{l}\text { Multi Source National Forest Inventory (MS-NFI) data, Natural Resources Institute Finland } \\
\text { 2018, Mäkisara et al., } 2016\end{array}$ \\
\hline Spatial drainage stage data on peatlands, resolution $25 \mathrm{~m} \times 25 \mathrm{~m}$ & Finnish Environment Institute \\
\hline Topography, digital elevation model (DEM), resolution $10 \mathrm{~m} \times 10 \mathrm{~m}$ & National Land Survey of Finland \\
\hline Daily and monthly climate data, resolution $10 \mathrm{~km} \times 10 \mathrm{~km}$ and $1 \mathrm{~km} \times 1 \mathrm{~km}$ & Finnish Meteorological Institute, Pirinen et al. (2012) \\
\hline Occurrence records of threatened mire plant species (at least $100 \mathrm{~m}$ resolution) & Finnish Environment Institute (Hertta), Rassi et al. (2010) \\
\hline Occurrence of mire plants and birds (at least $100 \mathrm{~m}$ resolution) & $\begin{array}{l}\text { Kainuu Centre for Economic Development, Transport and the Environment, Alanen and } \\
\text { Aapala (2015) }\end{array}$ \\
\hline $\begin{array}{l}\text { Greenhouse gas emission factors }\left(\mathrm{g}_{\text {gas }} \mathrm{m}^{-2} \text { year }^{-1} \text { ) for } \mathrm{CO}_{2}, \mathrm{CH}_{4} \text {, and } \mathrm{N}_{2} \mathrm{O} \text { (for }\right. \\
\text { details, see Table S21) }\end{array}$ & $\begin{array}{l}\text { Alm et al. (2007), Hyvönen et al. (2009), IPCC (2006, 2014), Minkkinen and Ojanen } \\
\text { (2013), Nykänen et al. (1996), Ojanen et al. (2010, 2013), Ojanen, Minkkinen and Penttiläa } \\
\text { (unpublished data), Regina et al. (1996), Salm et al. (2012), Shurpali et al. (2008), Sundh } \\
\text { et al. (2000), Väisänen et al. (2013) }\end{array}$ \\
\hline $\begin{array}{l}\text { Specific concentrations and specific exports of total nitrogen, total phosphorus, and } \\
\text { total organic carbon, } \mu \mathrm{g} \mathrm{L}^{-1} \text { or } \mathrm{kg} \mathrm{ha}^{-1} \text { (for details, see Table S31) }\end{array}$ & $\begin{array}{l}\text { Finér et al. (2010), Huhta and Jaakkola (1993), Joensuu et al. (2002), Kortelainen et al. } \\
\text { (2006), Mattsson et al. (2003, 2015); Myllys (2012), Nieminen et al. (2010, 2017); } \\
\text { Nieminen (unpublished data); Pöyry (2012) }\end{array}$ \\
\hline Peat price, $€ \mathrm{MWh}^{-1}$ & Statistics Finland (2018) \\
\hline
\end{tabular}

* The peatland mapping data for "Pohjois-Pohjanmaan ja Länsi-Kainuun suo-ohjelma" -project, Spatial dataset (unpublished).

** The peatland mapping data for "Pohjois-Pohjanmaan 3. Vaihemaakuntakaava" -project, Spatial dataset, 1.12.2016 (unpublished).

annual runoffs for each potential peat production site by using the FEMMA hydrological process model (Koivusalo et al., 2008). Then, we determined the specific concentrations (Palviainen et al., 2015) for the peat production option and the current land-use option and calculated the TN, TP, and TOC exports as the product of the runoff and specific concentrations. These specific concentrations were determined empirically and illustrate how much each land-use option increases the concentrations above the natural background level. The specific concentrations were obtained either directly from the literature or were based on additional analysis of the data presented in previous studies (Table 1, Table S31). To produce one variable for environmental loading to watercourses (named Water emissions hereafter), a specific common relative loading factor was calculated. It takes into consideration the specific impact of each element (TN, TP, and TOC) on water quality (for details of the simulations and calculations, see Supplement 3).

\subsection{Models}

We developed linear integer models to elaborate the social land-use planner's multi-objective peatland site selection problem. Consider a given geographical area with $n$ different sites that are suitable for peat production according to the given preliminary criteria. We denote the status of sites by $x_{j}(j=1, \ldots, n)$, which gets a value of 1 if the site $j$ is assigned as a peat production site in the master plan and 0 otherwise. In selecting the sites the land-use planner takes explicitly into account the size of sites but not their connectivity. The size of site $j$ is denoted by $a_{j}$. The overall target area for peat production is $A$. Let $N P V_{j}$ be the NPV of peat production at site $j$, that is, the economic value varies between the sites. We denote the Biodiversity value of site $j$ at the initial state before peat production is started by $B_{j}$. GHG and Water emissions of site $j$ caused by converting the site to peat production $\operatorname{are} C_{j}$ and $W_{j}$, respectively.

We supposed that a land-use planner seeks to maximize NPV of peat production with the given constraints related to environmental impacts, that is, the planner selects the peat production sites cost-effectively. We first consider a model which does not include any area target for peat production. Formally, the model (Model 1) can be expressed as follows: $\max _{x_{j}} \sum_{j=1}^{J} N P V_{j} x_{j}$ subject to constraints:

$\sum_{j=1}^{J} B_{j} x_{j} \leqslant B$

$\sum_{j=1}^{J} C_{j} x_{j} \leqslant C$

$\sum_{j=1}^{J} W_{j} x_{j} \leqslant W$

$x_{j} \in\{0,1\} \quad j=1, \ldots, n$

$\sum_{j=1}^{J} a_{j} x_{j} \leqslant A$

where $B, C$, and $W$ denote the target levels for Biodiversity loss, GHG emissions, and Water emissions, respectively. The objective function (1) sums NPVs of the selected sites. Constraint sets (2)-(4) ensure that Biodiversity loss and GHG and Water emissions impacts due to the selection of the peat production sites are smaller than or equal to the target levels. Constraint set (5) simply indicates that the choice variables must be binary, that is, each site is either assigned to peat production or not. Eq. (6) is the area constraint which ensures that the total area of the selected sites is smaller than or equal to the target area.

In what follows, we use the first model to reveal an efficiency frontier (also called a production possibility frontier) that illustrates two-dimensional trade-offs between NPV and the considered BES (Biodiversity loss, GHG emissions, and Water emissions) impacts. Therefore, we first solve the model using constraints (2)-(4) one by one with (1) and (5). The efficiency frontiers are revealed by solving the model multiple times with varying target levels of the considered BES variable. We repeat this procedure with the area constraint (6) to examine how the area restriction affects the two-dimensional trade-offs.

The second model (Model 2) is used to analyze multi-dimensional trade-offs between the economic returns and BES objectives. Model 2 includes (1) and (5) as well as the following restrictions:

$\sum_{j=1}^{J} B_{j} x_{j} \leq k B^{*}, k \leq 1$

$\sum_{j=1}^{J} C_{j} x_{j} \leq z C^{*}, z \leq 1$ 
$\sum_{j=1}^{J} W_{j} x_{j} \leq y W^{*}, y \leq 1$

where $k, z$, and $y$ are technical weight parameters that are varied to reveal the efficiency frontiers. The reference values for the three BES variables are denoted by $B^{*}, W^{*}$, and $C^{*}$ for Biodiversity loss, Water emissions, and GHG emissions, respectively. In addition to the Eqs. (1), (5), (7)-(9), the second model includes two area constraints to ensure that the target for the peat production area is achieved. The two area constraints are used to allow some flexibility in the site selection, because in the regional master plan the area target is only approximate and clearly larger than the actual peat production area that private peat production enterprises will eventually be able to utilize. Formally, the area constraints are

$\sum_{j=1}^{J} a_{j} x_{j} \leq A+50$

$\sum_{j=1}^{J} a_{j} x_{j} \geq A-50$

Model 2 is first solved without (7), (8), and (9), and the obtained Pareto-optimal solution is used to calculate the reference values for the three BES variables denoted by $B^{*}, C^{*}$, and $W^{*}$. These reference values are then used as initial target levels for the BES variables in the multidimensional analysis. To ensure that the Pareto-optimal solutions are found, we applied the $\varepsilon$-constraint method (Miettinen, 1999).

\section{Results}

\subsection{Characteristics of potential peat production sites}

The BES (Biodiversity loss and GHG and Water emissions) and economic (NPV) characteristics of potential peat production sites varied considerably (Table 2). The coefficient of variation (CV) was highest for the Water emissions ( $C V=1.3)$, followed by the NPV $(C V=1.1)$. NPV with a $3 \%$ discount rate was negative for twelve sites, indicating unprofitable peat production. The discount rate had a strong impact on the profitability of peat production, reflecting the fact that peat production occurs over a long time period. The production time was on average 37.3 years and varied from 18 to 62 years.

The characteristics of the potential peat production sites indicated strong variations, especially because GHG and Water emissions and NPV values were calculated on a per area basis, and the sites varied from 10 to 216 ha. The correlation between the size of the site and GHG emissions was strong $(r=0.952)$, whereas Biodiversity loss did not correlate significantly with the size of the site (Table 3 ). Correlations between peat production time and Water and GHG emissions were similar although weaker. Correlation coefficients between NPV of peat production and other variables were generally high, except for Biodiversity loss. Biodiversity loss showed high correlation $(r=0.62)$ only with Water emissions.

The values of Biodiversity loss and GHG and Water emissions are presented using a relative scale with respect to the NPV class based on the median NPV in Fig. 2. There were no sites that had lower Biodiversity loss than $27 \%$ of the maximum Biodiversity loss value. Otherwise, Biodiversity loss and GHG and Water emissions were relatively evenly distributed among the potential sites. The sites with low NPV

Table 2

Main characteristics of the potential peat production sites (99 sites).

\begin{tabular}{lllll}
\hline & Total & Mean & Min & Max \\
\hline Peat production area (ha) & 7168 & 72.4 & 10 & 216 \\
Biodiversity loss (index) & 137.6 & 1.4 & 0.9 & 3.1 \\
GHG emissions (Gg CO 2 equivalents) & 32710.5 & 330.4 & 26.5 & 1165.2 \\
Water emissions (index) & 1906.1 & 19.3 & 0.0 & 132.7 \\
NPV (k€) & 23117.8 & 233.5 & -189.6 & 1152.6
\end{tabular}

(NPV < median) seemed to involve lower GHG emissions than sites with high NPV (NPV $\geq$ median), as was also indicated by the correlation analysis (Table 3). Importantly, the potential peat production sites involved numerous different combinations of NPV of peat production, Biodiversity loss, GHG emissions, and Water emissions values. Therefore, the land-use planner is facing a challenging task to identify the set of sites that provides the targeted levels of these variables when selecting the potential peat production sites for master plan. Since all goals cannot be achieved simultaneously, compromises and sophisticated integrated assessment on trade-offs are needed. ${ }^{2}$

\subsection{Two-dimensional trade-offs}

As described in the Section 2.7 (Model 1), we first generated twodimensional efficiency frontiers that illustrate trade-offs between the economic (NPV) and each BES (Biodiversity loss, GHG emissions, Water emissions) objective separately (Fig. 3). When the area constraint for the potential peat production sites was excluded, we found, as expected, that a decrease in Biodiversity loss, GHG or Water emissions (compared to the level obtained at the maximum NPV) reduced NPV of peat production (Fig. 3a-c). However, the nature of the trade-offs differed between each BES objective. Water emissions could first be reduced without any significant loss in NPV of peat production, but further reduction clearly decreased it (Fig. 3c). This pattern was even clearer for the Biodiversity loss frontier (Fig. 3a), but the GHG emissions frontier was close to a straight line (Fig. 3b).

In this study, there was a quantitative target to assign approximately 2000 ha as peat production area in the regional master plan. Accounting for this area restriction in the optimization had a considerable effect on the trade-offs (Fig. 3aa, bb, cc); the production possibility set decreased and the efficiency frontiers moved closer to the origin. Under restricted areal optimization, the steep slope of the Biodiversity loss and the Water emission efficiency frontiers clearly differed from that of the GHG emissions efficiency frontier. Therefore, the range of total NPV in which cost-effective solutions were found was quite narrow varying from €6.9-11.2 and €8.5-11.2 million for Water emissions and Biodiversity loss, respectively. For GHG emissions, the range was significantly wider, $€ 2.3-11.2$ million. Under the area restriction, the values of BES variables at maximum NPV (without BES objectives) were: Biodiversity loss $=34.6$ units, GHG emissions $=11224 \mathrm{Gg} \mathrm{CO}_{2}$ equivalents, and Water emissions $=672.6$ units. Hence, the maximum potential for the reduction in Water emissions (571 units) was $84.9 \%$ from the Water emissions at maximum NPV. The percentage for reduction in GHG emissions was $44.9 \%$ and the potential maximum reduction in Biodiversity loss $51.2 \%$. These results show that the possibilities for avoiding harmful environmental impacts due to

\footnotetext{
${ }^{2}$ Notably, we used different time periods in calculating NPVs, because the peat production time varied between the sites. The use of different time periods in calculation is, however, problematic. For example, two sites with identical NPVs, one accumulating NPV over 20 years and the other over 60 years are very unlikely to be considered equally valuable by the land-use planner. The problem could be avoided by including present value of net revenues from some after-use option in the calculation, but it is not known how the sites will be used after peat production. However, we calculated a sensitivity analysis, where all sites were used in forestry after peat production by including forest land value in the NPV calculation (Faustmann, 1849). Peatlands are rather low productive areas in terms of timber production, and therefore, we used $100 € /$ ha as a land value in the test (Anonymous, 2013). With this land value the rank of sites in terms of NPV remained almost the same as without land value. The result indicates that the use of different time periods was not a severe problem in this study. In addition, potential peat production sites were not selected using only NPV as a criterion in the multi-objective optimization. Therefore, even though the rank based on NPV was not clear for all sites this had no effect on the optimal selection of sites as there were differences in environmental variables between the sites.
} 
Table 3

Correlation coefficients between selected variables (99 sites).

\begin{tabular}{|c|c|c|c|c|c|c|}
\hline & $N P V$ & Biodiversity loss & GHG emissions & Water emissions & Size of the site & Production time \\
\hline NPV & 1 & & & & & \\
\hline Biodiversity loss & 0.159 & 1 & & & & \\
\hline GHG emissions & $* * * 0.918$ & $* * * 0.286$ & 1 & & & \\
\hline Water emissions & $* * * 0.567$ & $* * * 0.620$ & $* * * 0.679$ & 1 & & \\
\hline Size of the site & $* * * 0.799$ & $* * * 0.342$ & $* * * 0.952$ & $* * * 0.657$ & 1 & \\
\hline Production time & $* * * 0.580$ & $* 0.169$ & $* * * 0.624$ & $* * * 0.452$ & $* * * 0.459$ & 1 \\
\hline
\end{tabular}

Note:

$* * *$ statistically significant at $1 \%$ level.

* statistically significant at $10 \%$ level

peat production under the area restriction differed considerably between the three BES variables.

\subsection{Multi-dimensional trade-offs}

When NPVs were maximized with the 2050 ha area constraint, the Pareto-optimal solution consisted of 24 peat production sites. This optimization solution was used as a benchmark for further examinations of multi-dimensional trade-offs. Technically, the trade-offs were revealed by systematically varying the weight parameters (Model 2: $k, z$, $y$ ) with 0.1 unit intervals until there were no more feasible solutions with the given weight parameter values. By using this procedure, 100 different Pareto-optimal solutions were identified. Multi-dimensional trade-offs between economic (NPV) and BES (Biodiversity loss, Water emissions, GHG emissions) objectives in the selection of 1950-2050 ha for peat production are presented in Table 4 with the associated weight values of the solutions. For interpretation, note that a weight value of 0.9 for Biodiversity loss, for example, indicates that Biodiversity loss of a particular solution is at least $10 \%$ smaller than Biodiversity loss of the benchmark solution. The weights of water and GHG emissions are to be interpreted in the same way.

The first thing to notice is that the interval of feasible weight values differed between the BES variables (Table 4). The feasible weight value intervals for Biodiversity loss, Water and GHG emissions were 1.0-0.5, $1.0-0.2$ and 1.0-0.6, respectively. Note also that the first solution in Table 4 describes the reference case in which NPV was maximized with weight values equal to 1 for all BES variables, that is, the BES objectives were set equal to the benchmark level.

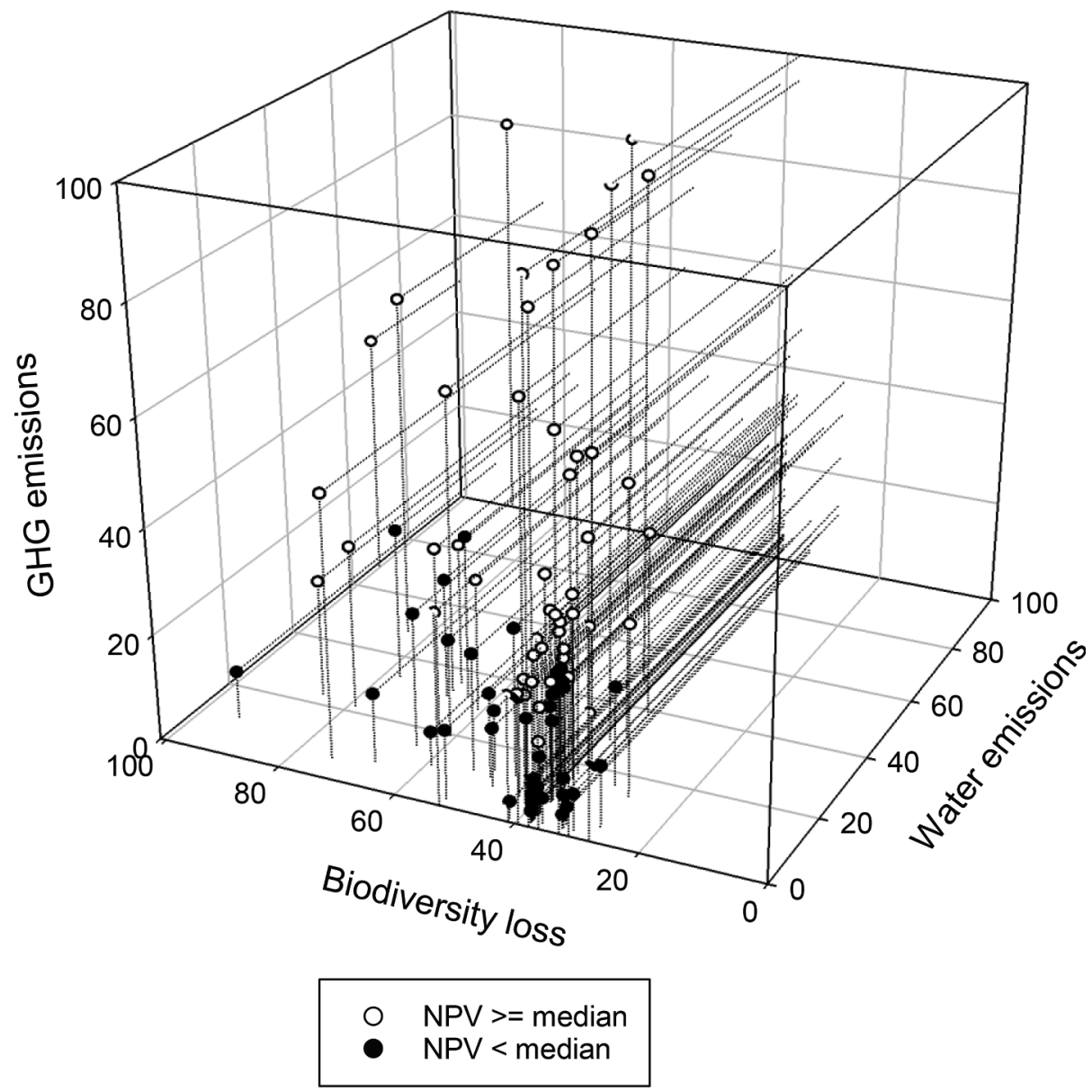

Fig. 2. Biodiversity loss, GHG emissions, and Water emissions of potential peat production sites by NPV classes. Variable values are presented on a relative scale, in which 100 equals the maximum value of the respective variable among the 99 peatland sites. 
a)

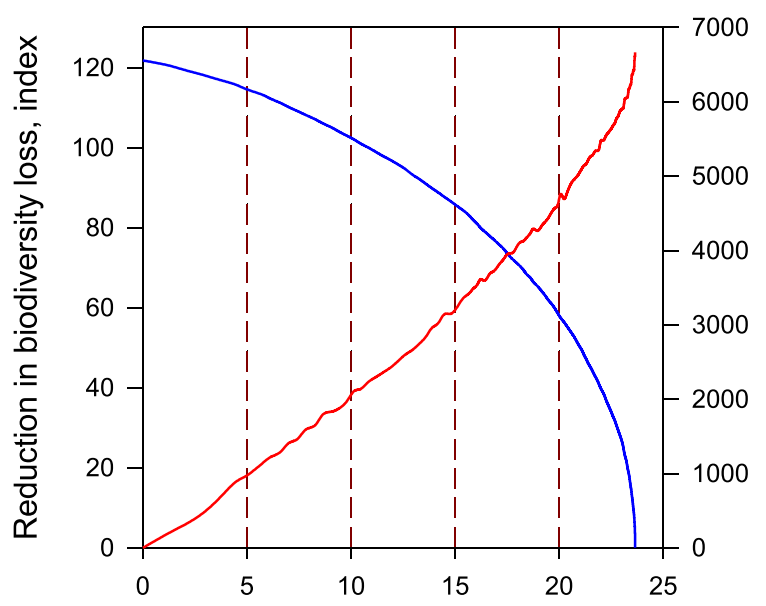

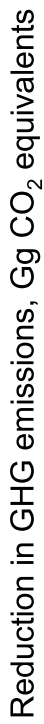

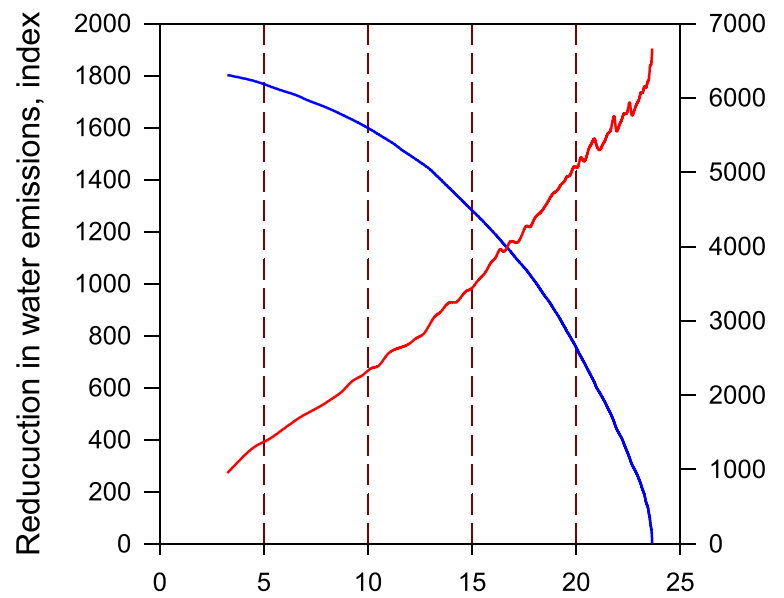

Net present value of peat production, mil. $€$ aa)

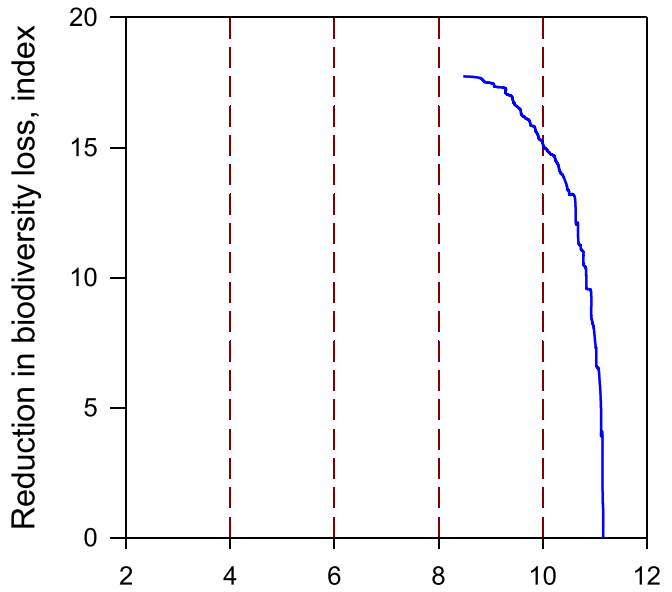

$\mathrm{bb)}$

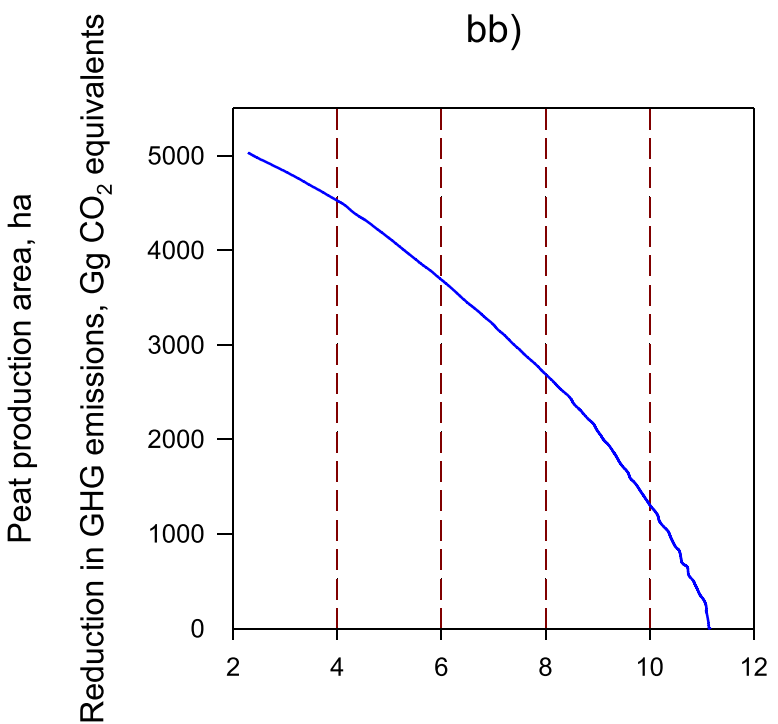

$\mathrm{cc})$

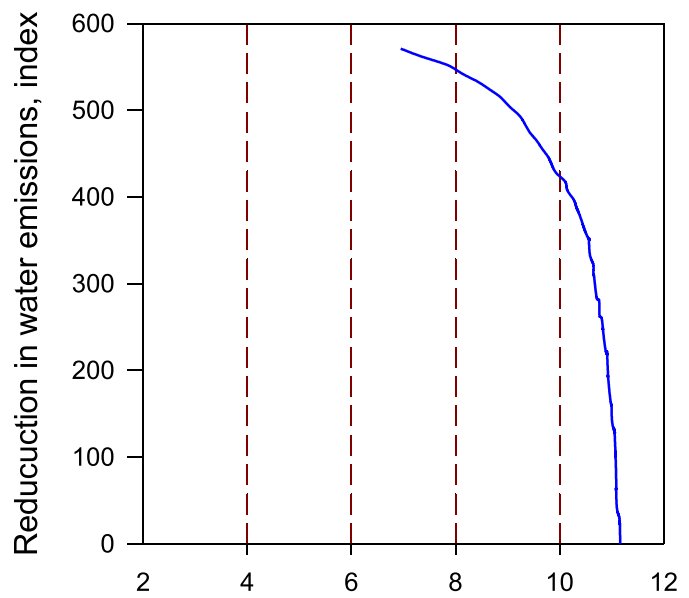

Net present value of peat production, mil. $€$

Fig. 3. Efficiency frontiers showing two-dimensional trade-offs between economic (NPV) and environmental (Biodiversity loss, GHG emissions, Water emissions) targets in the selection of peat production sites. The values of environmental variables are shown as reduction from the level that was obtained at the maximum NPV. Left hand panels show the efficiency frontiers (blue lines) without the area restriction and the hectares assigned to the peat production (red lines). Right hand panels include the efficiency frontiers with the area restriction (1950-2050 ha) for peat production. Only potential production sites with a positive NPV are included (87 sites). (For interpretation of the references to colour in this figure legend, the reader is referred to the web version of this article.) 
Table 4

Pareto-optimal solutions for multi-objective selection of peat production sites.

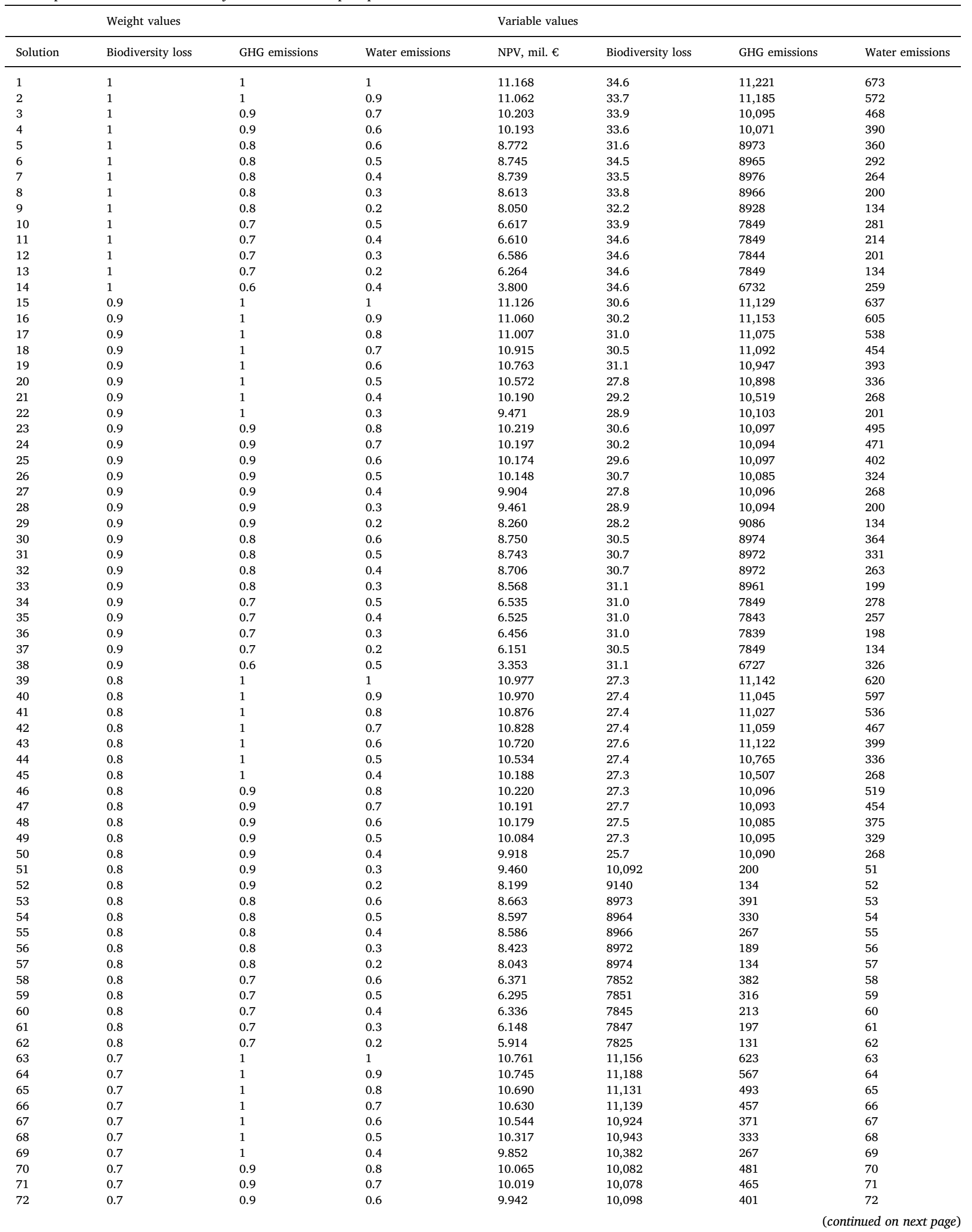


Table 4 (continued)

\begin{tabular}{|c|c|c|c|c|c|c|c|}
\hline & Weight values & & & Variable valu & & & \\
\hline Solution & Biodiversity loss & GHG emissions & Water emissions & NPV, mil. $€$ & Biodiversity loss & GHG emissions & Water emissions \\
\hline 73 & 0.7 & 0.9 & 0.5 & 9.911 & 10,082 & 299 & 73 \\
\hline 74 & 0.7 & 0.9 & 0.4 & 9.782 & 10,092 & 261 & 74 \\
\hline 75 & 0.7 & 0.9 & 0.3 & 9.157 & 9928 & 202 & 75 \\
\hline 76 & 0.7 & 0.8 & 0.6 & 8.406 & 8968 & 379 & 76 \\
\hline 77 & 0.7 & 0.8 & 0.5 & 8.321 & 8959 & 330 & 77 \\
\hline 78 & 0.7 & 0.8 & 0.4 & 8.205 & 8977 & 265 & 78 \\
\hline 79 & 0.7 & 0.8 & 0.3 & 8.196 & 8970 & 192 & 79 \\
\hline 80 & 0.7 & 0.8 & 0.2 & 7.456 & 8813 & 132 & 80 \\
\hline 81 & 0.7 & 0.7 & 0.4 & 5.776 & 7830 & 221 & 81 \\
\hline 82 & 0.7 & 0.7 & 0.3 & 5.703 & 7825 & 199 & 82 \\
\hline 83 & 0.6 & 1 & 0.8 & 10.387 & 11,136 & 506 & 83 \\
\hline 84 & 0.6 & 1 & 0.7 & 10.298 & 10,916 & 466 & 84 \\
\hline 85 & 0.6 & 1 & 0.6 & 10.230 & 11,040 & 401 & 85 \\
\hline 86 & 0.6 & 1 & 0.5 & 9.875 & 10,694 & 333 & 86 \\
\hline 87 & 0.6 & 0.9 & 0.7 & 9.635 & 10,075 & 426 & 87 \\
\hline 88 & 0.6 & 0.9 & 0.6 & 9.627 & 10,091 & 398 & 88 \\
\hline 89 & 0.6 & 0.9 & 0.5 & 9.522 & 10,075 & 328 & 89 \\
\hline 90 & 0.6 & 0.9 & 0.4 & 9.187 & 9994 & 266 & 90 \\
\hline 91 & 0.6 & 0.9 & 0.3 & 8.328 & 9564 & 200 & 91 \\
\hline 92 & 0.6 & 0.8 & 0.7 & 7.803 & 8968 & 407 & 92 \\
\hline 93 & 0.6 & 0.8 & 0.6 & 7.801 & 8950 & 381 & 93 \\
\hline 94 & 0.6 & 0.8 & 0.5 & 7.738 & 8949 & 336 & 94 \\
\hline 95 & 0.6 & 0.8 & 0.4 & 7.714 & 8977 & 269 & 95 \\
\hline 96 & 0.6 & 0.8 & 0.3 & 7.486 & 8948 & 199 & 96 \\
\hline 97 & 0.5 & 1 & 0.7 & 9.064 & 10,217 & 457 & 97 \\
\hline 98 & 0.5 & 1 & 0.6 & 8.852 & 10,196 & 397 & 98 \\
\hline 99 & 0.5 & 0.9 & 0.7 & 8.983 & 10,063 & 469 & 99 \\
\hline 100 & 0.5 & 0.9 & 0.5 & 8.742 & 10,068 & 334 & 100 \\
\hline
\end{tabular}

It is noteworthy that the reduction in Biodiversity loss did not cause reduction in GHG or Water emissions. For example, when Biodiversity loss was 10\% lower than in the benchmark and GHG emissions were not restricted (GHG weight value $=1$ ), Water emissions varied according to its own weight value (see solutions 15-22 in Table 4). Water emissions would have reduced more strongly if the reduction in Biodiversity loss had caused the reduction in Water emissions. This outcome indicates that the Biodiversity loss objective lacked synergy with the GHG and Water emissions objectives.

Including restrictions in GHG emissions clearly reduced NPV of peat production compared with the benchmark level. Notably, restriction in GHG emissions also resulted in reduction in Water emissions, in particular at the higher target levels of emissions reductions. For example, solution 7 with 20\% lower GHG emissions compared with the benchmark level enabled 40\% reduction in Water emissions, thus the solutions with $0-30 \%$ Water emissions reductions were not Pareto-optimal.

Despite that the Biodiversity loss objective did not influence the GHG and Water emissions objectives, reduction in Water emissions reduced Biodiversity loss. For example, in the case when Water emissions were at least $20 \%$ lower than in the benchmark and there were no restrictions in GHG emissions, it was possible to reduce Biodiversity loss by $10 \%$ at the same time (see solutions $17-22$ in Table 4). Additionally, when the Water emissions reduction target was set to $80 \%$ it was possible to obtain reductions in Biodiversity loss and GHG emissions in some solutions (e.g., solutions 29 and 57).

To further investigate the features of the Pareto-optimal solutions, an additional analysis was conducted in which the average characteristics of the selected and non-selected potential production sites were calculated. Only solutions 1-50 are presented in this paper (Table 5). In general, the average NPV of peat production was clearly higher and the average Biodiversity loss and Water emissions values were lower for the selected sites than for the non-selected sites, the outcome depending strongly on the weight values. GHG emissions were lower for the selected sites only with the GHG weight value of $\leq 0.7$. When the BES objectives had a weight value close to 1.0 , the difference in the NPV per hectare value was higher and the difference in the BES variables was lower between the selected and the non-selected sites. The opposite pattern was observed when the weight values were lower. In particular, the solutions 14 and 38 in which GHG weight was 0.6 indicated lower average NPV per hectare for the selected than non-selected sites. A decrease in Biodiversity loss resulted in the selection of larger sites (e.g., the number of selected sites lower in solutions 15-38 than 1-4). In addition, putting greater emphasis on BES objectives decreased to some extent the average peat production time of the selected sites.

\section{Discussion}

Land-use planning involves trade-offs between BES and economic returns that are difficult to assess in an explicit and systematic way. In this study, we developed and utilized multi-objective numeric optimization models to analyze the trade-offs associated with the selection of potential peat production sites as part of the development of a regional master plan in northern Finland. The examined BES variables, which were identified to be relevant for the local authority, were Biodiversity loss, GHG emissions, Water emissions. In addition, to address provisioning services we examined economic returns measured by NPV of peat production.

The novelty of our study is made up of a number of factors that are rarely dealt with in the literature. First, the cost-effectiveness analysis by applying multi-objective optimization has been widely applied to solve complex land-use and land-management problems involving multiple ecosystem services and their trade-offs (e.g., Nelson et al., 2008; Polasky et al., 2008; Triviño et al., 2015; Kennedy et al., 2016; Pennington et al., 2017), but as far as we know, it has not been used for peatland use planning. Second, we considered a real-life land-use planning problem and conducted the research interactively with the regional land-use planner. The outcome of our work is realized in the ratified land-use master plan (Council of Oulu Region, 2018). Several authors have addressed that despite recent advantages in ecosystem service research the implementation of ecosystem service concept at the 
Table 5

The average characteristics of selected and non-selected sites in the Pareto-optimal solutions.

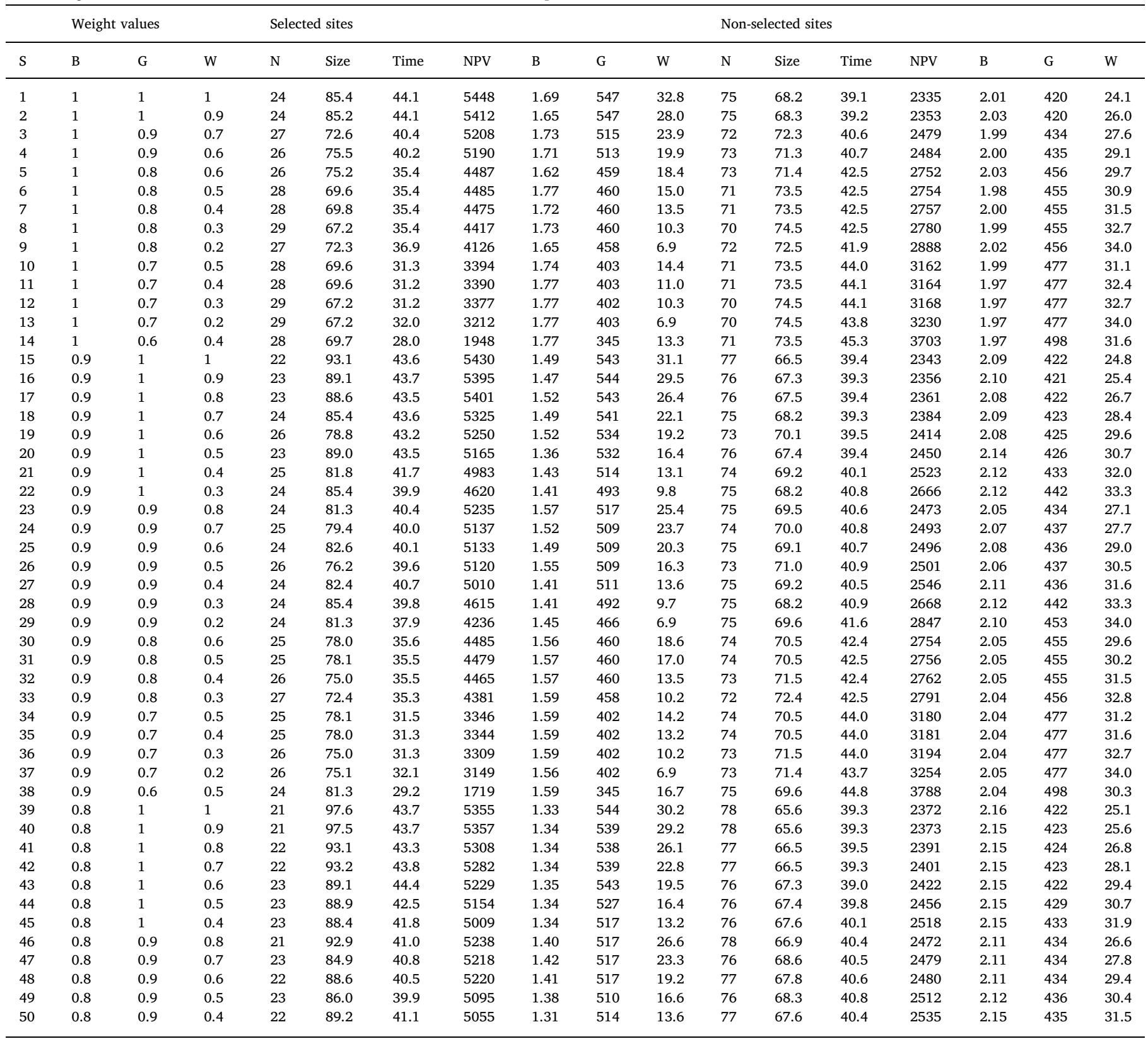

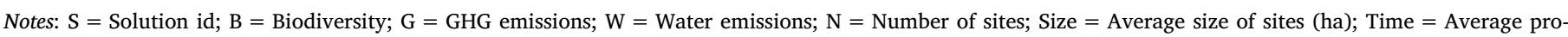

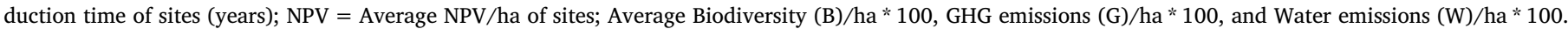
The averages are weighted by the size of the site.

regional and local levels of planning remains poor and the bridge between research and decision making is yet to be built (e.g., Rall et al., 2015; Tammi et al., 2017). Finally, the study presents an ideal example of how available environmental spatial data can be used in a comprehensive manner to generate long-term model predictions that effectively track the dynamics of trade-offs between BES and capture their spatial variability (Schröter et al., 2015).

Our results show that despite trade-offs between economic returns and BES there are ways to improve environmental performance through careful planning of land-use without imposing large costs. For example, reduction in Water emissions by $20 \%$ with a concurrent decrease in Biodiversity loss by $20 \%$ relative to the benchmark levels reduced NPV of peat production by only $2.6 \%$. These results are similar to previous studies in which relatively high environmental benefits were achieved with a low reduction in economic returns. For example, Pennington et al. (2017) showed that reorganizing land-use and land management reduced the baseline phosphorus loads due to agricultural runoff by $20 \%$ and sediment loads by $18 \%$ without any reduction in the annual net returns from agriculture.

On the other hand, our results also show that considerable reductions in Biodiversity loss and Water emissions increased costs significantly. For example, $30 \%$ reduction in Biodiversity loss concurrently with $70 \%$ reduction in Water emissions (and 30\% reduction in GHG emissions) reduced NPV of peat production by $49 \%$ from the benchmark level. This was also found by Triviño et al. (2015) who examined joint timber production and carbon storage: the first increments in carbon storage or sequestration from an optimal timber production level were inexpensive, but further efforts in carbon sequestration 
increased the costs considerably. Typically, the more ambitious are the objectives of biodiversity conservation and those of regulating and cultural services, the more the net returns from provisioning services are reduced, and vice-versa (Nelson et al., 2009; Gascoigne et al., 2011; Pennington et al., 2017). In our case, restricting the total area of peat production to 2000 ha further reduced the possibility of avoiding negative BES impacts, as no less than 2000 ha could be allocated to peat production no matter how detrimental the BES impacts. Thus, there was a limit to what could be accomplished with the given area restriction and without significant reductions in the net returns from peat production. Hence, the land-use planner should note that when selecting valuable BES sites for peat production in the master plan, the profitability of peat production is reduced significantly and many of the selected sites will eventually not be used for peat production.

Unlike Biodiversity loss and Water emissions, reduction in GHG emissions decreased NPV linearly, without any threshold. In addition, the possibility to avoid harmful environmental impacts of peat production was significantly lower for GHG emissions than Biodiversity or Water emissions. GHG emissions are unavoidable when peat is burned. GHG emissions are governed by the volume of peat, which typically increases with the size of production site. These features cause challenges in reducing GHG emissions when peat production and burning is allowed.

Earlier life-cycle analyses on peat production in boreal peatlands (Kirkinen et al., 2007; Väisänen et al., 2013) have shown that GHG emissions can be reduced efficiently by site allocation. When the emissions from the current land-use are high, such as peatlands drained for agriculture, allocating peat production to those sites could have potential for emission reductions. However, only a few percent of peatlands are under agriculture in Finland (Päivänen and Hånell, 2012). This was also observed in this study: only 10 of the 99 studied sites had greater agricultural peatland coverage than $10 \%$. In forestrydrained peatlands, such as the majority of the sites in our study, high levels of GHG emissions are exceptional (Ojanen et al., 2013). Hence, allocation of peat production to high-emissions sites may, after all, have very limited use in reducing GHG emissions.

From the above discussion a question arises, whether it is reasonable to use GHG emissions as an environmental criterion in the allocation of potential energy peat production sites. GHG emissions reduction as an objective in land-use planning will undermine the profitability of potential peat production. Hence, when peat production is allowed as a land-use option in the first place, it may not be costefficient to restrict the associated GHG emissions through land-use planning. A better option may be to use the prevailing policy instruments, such as national energy taxes and the EU Emission Trading System, to control fuel prices and let the energy market determine the demand for alternative fuels. In our case, there was a given area requirement, 2000 ha, for land-use planning, but the demand for peat will eventually determine the area taken into production.

Water quality is an important local environmental issue related to many land-use and land-management decisions (e.g., Polasky et al., 2011; Kennedy et al., 2016; Pennington et al., 2017). Water quality has also been observed to be a significant factor in explaining variations in people's preferences for alternative uses of peatlands (Tolvanen et al., 2013). Our results showed that there are two ways to cost-efficiently reduce Water emissions through land-use planning. First, reduction can be obtained by allocating potential peat production sites to agricultural peatlands with typically high water emissions. Owing to the small area of agricultural peatlands, this is again not an efficient means of decreasing emissions on a large-scale. The second option would be to allocate peat production to those peatland forests where Water emissions are high. However, this is also not a very straightforward means to decrease emissions, since, whereas phosphorus exports are generally higher from low-productivity peatlands (Nieminen, 2003, Kaila et al., 2014), carbon and nitrogen exports are highest from fertile peatland sites (Nieminen, 2004, Kaila et al., 2015). Due to high variation in the effects of forest management on water quality, comparison of Water emissions between peat production and forest management is very site specific (see Supplement 3 for details).

Reduction in Biodiversity loss had little impact on GHG and Water emissions. The reason may lie in the site characteristics of potential peat production sites. An important criterion for site selection was a thick peat layer, which is generally associated with sites of low vegetation diversity (Laine et al., 1995). The number of threatened species, one of the criteria producing the Biodiversity loss value, was also low at these sites. The overall low biodiversity indicates that there was little potential to decrease Biodiversity loss through the selection of peat production sites, as was also revealed in the Pareto-optimal solutions.

Another reason for low synergy between Biodiversity loss and GHG and Water emissions may be that, unlike GHG and Water emissions, Biodiversity loss was not directly linked to the size of the site or peat production time. There was an indirect linkage, however, as our variables producing Biodiversity loss value, such as number of mire complex types, habitat types and geomorphological formations, are likely linked to the size of the site. The fact that the area size had minor effect in our study is again probably because our peatland sites were relatively homogeneous and naturally species-poor ecosystems. Nevertheless, although Biodiversity loss was calculated in a policy relevant manner using similar criteria as used nationally and in former regional master planning, it is clear that some of the effect of area size on biodiversity was lost. A subject of further research is therefore how the size of site affects its biodiversity value.

Unlike Biodiversity loss, GHG and Water emissions were calculated on per size of the site and peat production time basis, which apparently explains their strong synergy. Previous studies have applied varying practices regarding the effect of size of sites on ecosystem service provision. In Nelson et al. (2009), biodiversity value (the potential for habitats to support a suite of vertebrate animals) was dependent on the area of suitable habitats, and many other ecosystem services were also linked to the area.

Multi-objective optimization provides a systematic approach to explicitly examine trade-offs between BES and economic returns for landuse planning. However, quantification of ecosystem services for the multi-objective optimization and for methods assessing trade-offs in ecosystem services involves many uncertainties (Cavander-Bares et al., 2015). Further research to test and validate model predictions that are utilized in the optimization is needed to reduce these uncertainties. For example, impacts of peat quality on GHG and Water emissions, the differences in environmental loading between sites and geographical regions, and the impacts of climate change on BES need further research. In addition, there are challenges to estimate economic returns because production costs are private information and are not directly measurable by researchers (Armsworth et al., 2012).

Despite the uncertainties involved in multi-objective optimization, our analyses showed that it produces useful estimates of the economic and environmental outcomes of alternative land- uses, thereby providing meaningful information to decision makers. In the selection of potential peat production sites, the local land-use planner may avoid significant negative environmental impacts, but must take into account that all objectives may not be achieved simultaneously. Hence, prioritizing the objectives is necessary, and for that purpose the method can be developed further. An interesting avenue for future research could be to incorporate benefit-relevant indicators (Olander et al., 2017) or social values (Glenk et al., 2014; Pennington et al., 2017) into the optimization framework to achieve a deeper understanding of both the ecological supply and the social demand for the BES.

\section{Acknowledgements}

This paper received support from EU LIFE + Programme (LIFEPeatLandUse, LIFE12ENV/FI/150) and is a delivery to the Nordic Centre of Excellence Biowater (Nordforsk, 82263). 


\section{Appendix A. Supplementary data}

Supplementary data to this article can be found online at https:// doi.org/10.1016/j.ecoser.2019.101027.

\section{References}

Alanen, A., Aapala, K. (eds), 2015. Soidensuojelutyöryhmän ehdotus soidensuojelun täydentämiseksi (Proposal of the Mire Conservation Group for supplemental mire conservation). Ympäristöministeriön raportteja 26, Helsinki, Finland. Available at: https://helda.helsinki.fi/handle/10138/158285. (Accessed 29.8.2018).

Albrecht, E., Ratamäki, O., 2016. Effective arguments for ecosystem services in biodiversity conservation - A case study on Finnish peatland conservation. Ecosyst. Serv. $22,41-50$.

Alm, J., Shurpali, N.J., Minkkinen, K., Aro, L., Hytönen, J., Laurila, T., et al., 2007. Emission factors and their uncertainty for the exchange of $\mathrm{CO}_{2}, \mathrm{CH}_{4}$ and $\mathrm{N}_{2} \mathrm{O}$ in Finnish managed peatlands. Boreal Environ. Res. 12 (2), 191-209.

Anonymous, 2013. Suomen Säädöskokoelma 309/2013. Valtioneuvoston asetus riistavahingoista. (in Finnish).

Armsworth, P., Acs, S., Dallimer, M., Gaston, K., Hanley, N., Wilson, P., 2012. The cost of policy simplification in conservation incentive programs. Ecol. Lett. 15, 406-414.

Cajander, A.K., 1913. Studien über die Moore Finnlands. Acta Forestalia Fennica 2, $1-208$.

Cavander-Bares, J., Polasky, S., King, E., Balvanera, P., 2015. A sustainability framework for assessing trade-offs in ecosystem services. Ecol. Soc. 20, 17.

Chapman, S., Buttler, A., Francez, A.-J., Laggoun-Défarge, F., Vasander, H., Schloter, M., Combe, J., Grosvernier, P., Harms, H., Epron, D., Gilbert, D., Mitchell, E., 2003. Exploitation of northern peatlands and biodiversity maintenance: a conflict between economy and ecology. Front. Ecol. Environ. 1, 525-532.

Compton, P., Devuyst, D., Hens, L., Nath, B. (Eds.), 2013. Environmental Management in Practice: Vol 3: Managing the Ecosystem. Routledge, New York, USA., pp. 328 Kindle Edition.

Council of Oulu Region, 2018. Pohjois-Pohjanmaan maakuntakaavan uudistaminen, 3 vaihemaakuntakaava, Kaavaselostus hyväksytty (In Finnish). 183 pp. Available at: https://www.pohjois-pohjanmaa.fi/file.php?5609. (Accessed 21.8.2019).

De Fries, R., Foley, J.A., Asner, G.P., 2004. Land-use choices: a balancing human needs and ecosystem function. Front. Ecol. Environ. 2 (5), 249-257.

Deng, X., Zhihui, L., Gibson, J., 2016. A review on trade-off analysis of ecosystem services for sustainable land-use management. J. Geographical Sci. 26, 953-968.

Evans, C.D., Bonn, A., Holden, J., Reed, M.S., Evans, M.G., Worrall, F., Parnell, M., 2014. Relationships between anthropogenic pressures and ecosystem functions in UK blanket bogs: linking process understanding to ecosystem service valuation. Ecosyst. Serv. 9, 5-19.

Faustmann, M., 1849. Berechnung des Wertes welchen Waldboden sowie noch nicht haubare Holzbestände für die Waldwirtschaft besitzen. Allgemeine Forst- und JagdZeitung, vol.15. Republished in 1995 with the title "Calculation of the value which forest land and immature stands possess for forestry". J. For. Econ. 1, 7-44.

Finér, L., Mattsson, T., Joensuu, S., Koivusalo, H., Laurén, A., Makkonen, T., Nieminen, M., Tattari, S., Ahti, E., Kortelainen, P., Koskiaho, J., Leinonen, A., Nevalainen, R., Piirainen, S., Saarelainen, J., Sarkkola, S., Vuollekoski, M., 2010. Metsäisten valumaalueiden vesistökuormituksen laskenta (A method for calculating nitrogen, phosphorus and sediment load from forested catchments). Suomen ympäristö 10 , Helsinki, Finland. Available at: https://helda.helsinki.fi/bitstream/handle/10138/ 37973/SY_10_2010.pdf? sequence $=1$ \&isAllowed $=$ y. (Accessed 29.8.2018).

Finnish Environment Institute, 2018. CORINE Land Cover 2012, 20m (CLC2012). Available at: http://www.syke.fi/en-US/Open information/Spatial datasets. (Accessed 29.8.2018).

Finnish Statistical Yearbook of Forestry, 2014. Finnish Forest Research Institute, Vantaa, Finland.

Flyktman, M., 2005. Energia- ja ympäristöturpeen kysyntä ja tarjonta vuoteen 2020 mennessä. VTT, tutkimusselostus, PR02/2085/05, Jyväskylä, Finland.

Gascoigne, W.R., Hoag, D., Koontz, L., Tangen, B.A., Shaffer, T.L., Gleson, R.A., 2011. Valuing ecosystem and economic services across land-use scenarios in the Prairie Pothole region of the Dakotas, USA. Ecol. Econ. 70, 1715-1725.

Glenk, K., Schaaffsma, M., Moxey, A., Martin-Ortega, J., Hanley, N., 2014. A framework for valuing spatially targeted peatland restoration. Ecosyst. Serv. 9, 20-33.

Grêt-Regamey, A., Siren, S., Brunner, S.H., Weibel, B., 2017. Review of decision support tools to operationalize the ecosystem service concept. Ecosyst. Serv. 26 (Part B), 306-315.

Haara, A., Pykäläinen, J., Tolvanen, A., Kurttila, M., 2018. Use of interactive data visualization in multi-objective forest planning. J. Environ. Manage. 210, 71-86.

Härmä, P., Huttunen, S., Törmä, M., Järvenpää, E., Kallio, M., Teiniranta, R., Kiiski, T., Suikkanen, J., 2013. GIO Land Monitoring 2011-2013 in the framework of regulation (EU) No 911/2010. Pan-Eu Component. Final Report. Finland. European Environment Agency. Available at: https://www.researchgate.net/publication/ 280879439_Corine_2012_Final_Report_Finland_GIO_Land_Monitoring_2011_-2013 in the framework of regulation_EU_No_9112010_-Pan-EU_Component - Grant Agreement_3541B2012R0-GIOEEA55037. (Accessed 29.8.2018).

Hauck, J., Görg, C., Varjopuro, R., Ratamäki, O., Maes, J., Wittmer, H., Jax, K., 2013. "Maps have an air of authority": potential benefits and challenges of ecosystem service maps at different levels of decision making. Ecosyst. Serv. 4, 25-32.

Hermanns, T., Helming, K., Köning, H.J., Schimdt, K., Li, Q., Faust, H., 2017. Sustainability impact assessment of peatland-use scenarios: confronting land use supply with demand. Ecosyst. Serv. 26, Part B 365-376.
Huhta, H., Jaakkola, A., 1993. Viljelykasvien ja lannoituksen vaikutus ravinteiden huuhtoutumiseen turvemaasta Tohmajärven huuhtoutumiskentällä v 1983-87. Maatalouden Tutkimuskeskus, Tiedote 20/93, Jokioinen, Finland.

Hyvönen, N., Huttunen, J., Shurpali, N., Tavi, N., Repo, M., Martikainen, P., 2009. Fluxes of nitrous oxide and methane on an abandoned peat extraction site: effect of reed canary grass cultivation. Bioresour. Technol. 100 (20), 4723-4730.

Inostroza, L., König, H., Zhen, L., Pickard, B., 2017.. Putting ES into practice (special issue). Ecosyst. Serv. 26 (Part B), 303-482.

IPCC, 2006. IPCC 2006 Guidelines for National Greenhouse Gas Inventories, Prepared by the National Greenhouse Gas Inventories Programme. Institute for Global Environmental Strategies, Japan.

IPCC, 2014. 2013 Supplement to the 2006 IPCC Guidelines for National Greenhouse Gas Inventories: wetlands. IPCC, Switzerland.

Joensuu, S., Ahti, E., Vuollekoski, M., 2002. Effects of ditch network maintenance on the chemistry of run-off water from peatland forests. Scand. J. For. Res. 17, 238-247.

Joosten, H., Clarke, D., 2002. Wise use of Mires and Peatlands - Background and Principles Including a Framework for Decision-Making. International Mire Conservation Group and International Peat Society, Greifswald, Germany and Jyväskylä, Finland.

Kaila, A., Sarkkola, S., Laurén, A., Ukonmaanaho, L., Koivusalo, H., Xiao, L., O’Driscoll, C., Tervahauta, A., Nieminen, M., 2014. Phosphorus export from drained Scots pine mires after clear-felling and bioenergy harvesting. For. Ecol. Manage. 325, 99-107.

Kaila, A., Laurén, A., Sarkkola, S., Koivusalo, H., Ukonmaanaho, L., O’Driscoll, C., Xiao, L., Asam, Z., Nieminen, M., 2015. Effect of clear-felling and harvest residue removal on nitrogen and phosphorus export from drained Norway spruce mires in southern Finland. Boreal Env. Res. 20, 693-706.

Kareksela, S., Moilanen, A., Tuominen, S., Kotiaho, J.S., 2013. Use of inverse spatial conservation prioritization to avoid biological diversity loss outside protected areas. Conserv. Biol. 27 (6), 1294-1303.

Kennedy, C.M., Hawthorne, P.L., Miteva, D.A., Baumgarten, M., Sochi, K., Matsumoto, M., Evans, J.S., Polasky, S., Hamel, P., Viera, E.M., Develey, P.R., Sekerciogly, C.H., Davidson, A.D., Uhlhorn, M.E., Kiesecker, J., 2016. Optimizing land use decisionmaking to sustain Brazilian agricultural profits, biodiversity and ecosystem services. Biol. Conserv. 204, 221-230.

Kirkinen, J., Minkkinen, K., Penttilä, T., Kojola, S., Sievänen, R., Alm, J., Saarnio, S., Silvan, N., Laine, J., Savolainen, I., 2007. Greenhouse impact due to different peat fuel utilisation chains in Finland - a life-cycle approach. Boreal Environ. Res. 12 (2), 211-223.

Koivusalo, H., Ahti, E., Laurén, A., Kokkonen, T., Karvonen, T., Nevalainen, R., Finér, L., 2008. Impacts of ditch cleaning on hydrological processes in a drained peatland forest. Hydrol. Earth Syst. Sci. 12, 1211-1227.

Kortelainen, P., Mattsson, T., Finér, L., Ahtiainen, M., Saukkonen, S., Sallanataus, T. 2006. Controls on the export of C, N, P and Fe from undisturbed boreal catchments. Finland. Aquat. Sci. 68, 453-468.

Laine, J., Vasander, H., Laiho, R., 1995. Long-term effects of water level drawdown on the vegetation of drained pine mires in southern Finland. J. Appl. Ecol. 32, 785-802.

Law, E., Bryan, B., Meijaard, E., Mallawaarahchi, T., Struebig, M., Watts, M., Wilson, K. 2017. Mixed policies give more options in multifunctional tropical forest landscapes. J. Appl. Ecol. 54, 51-60.

Maes, J., Paracchini, M.L., Zulian, G., Dunbar, M.B., Alkemade, R., 2012. Synergies and trade-offs between ecosystem service supply, biodiversity, and habitat conservation status in Europe. Biol. Conserv. 155, 1-12.

Mäkisara, K., Katila, M., Peräsaari, J., Tomppo, E., 2016. The Multi-Source National Forest Inventory of Finland - methods and results 2013. Natural resources and bioeconomy studies 10/2016, Natural Resources Institute Finland. Available at: http://urn.fi/URN:ISBN:978-952-326-186-0. (Accessed 28.9.2018).

Martin-Ortega, J., Allott, T.E.H., Glenk, K., Schaafsma, M., 2014. Valuing water quality improvements from peatland restoration: evidence and challenges. Ecosyst. Serv. 9, 34-43.

Mattsson, T., Finér, L., Kortelainen, P., Sallantaus, T., 2003. Brook water quality and background leaching from unmanaged forested catchments in Finland. Water Air Soil Pollut. 147, 275-297.

Mattsson, T., Kortelainen, P., Räike, A., Lepistö, A., Thomas, D.N., 2015. Spatial and temporal variability of organic $\mathrm{C}$ and $\mathrm{N}$ concentrations and export from 30 boreal rivers induced by land use and climate. Sci. Total Environ. 508, 145-154.

Miettinen, K., 1999. Nonlinear Multiobjective Optimization. Kluwer Academic Publishers, Boston, MA, USA.

Millennium Ecosystem Assessment, 2005. Ecosystems and Human Well-being: Synthesis. Island Press, Washington, DC, USA.

Ministry of Agriculture and Forestry, 2012. Government decision on the sustainable use and protection of mires and peatlands (in Finnish). Available at: https://mmm.fi/ documents/1410837/1516663/MMM-119690-v5-suostrategia valtioneuvoston periaatepaatos v4/005425e8-e3c4-497d-8cff-26f343896c37/MMM-119690-v5suostrategia_valtioneuvoston_periaatepaatos_v4.pdf. (Accessed 10.6.2019).

Ministry of Economic Affairs and Employment of Finland, 2013. National Energy and Climate strategy. Available at: https://tem.fi/documents/1410877/2769658/ National + Energy + and + Climate + Strategy + 2013/630dc2c6-4a23-4f2e-b3043cd69daf8265/National + Energy + and + Climate + Strategy + 2013.pdf. (Accessed 29.8.2018).

Minkkinen, K., Ojanen, P., 2013. Pohjois-Pohjanmaan turvemaiden kasvihuonekaasutaseet. Metla Working Papers 258. Finnish Forest Research Institute, Vantaa, Finland. pp. 75-111.

Myhre, G., Shindell, D., Bréon, F.-M., Collins, W., Fuglestvedt, J., Huang, J., Koch, D. Lamarque, J.-F., Lee, D., Mendoza, B., Nakajima, T., Robock, A., Stephens, G., Takemura, T., Zhang, H., 2013. Anthropogenic and Natural Radiative Forcing. In: Stocker, T.F., Qin, D., Plattner, G.-K., Tignor, M., Allen, S.K., Boschung, J., Nauels, A., 
Xia, Y., Bex, V., Midgley, P.M. (Eds.), Climate Change 2013: The Physical Science Basis. Contribution of Working Group I to the Fifth Assessment Report of the Intergovernmental Panel on Climate Change. Cambridge University Press, Cambridge, United Kingdom and New York, USA.

Myllys, M., 2012. Turvemaiden viljelyn vesistövaikutuksista - huuhtoutumis- ja lysimetrikentältä saatuja tuloksia. Presentation in symposium: "Loading from mires and peatlands in Finland", the Finnish Peatland Society, 17.10.2012. (in Finnish).

Natural Resources Institute Finland, 2018. Multi Source National Forest Inventory (MS NFI) data. Available at: http://kartta.luke.fi/. (Accessed 31.8.2018).

Nelson, E., Polasky, S., Lewis, D.J., Plantinga, A.J., Lonsdorf, E., White, D., Bael, D., Lawler, J.J., 2008. Efficiency of incentives to jointly increase carbon sequestration and species conservation on a landscape. PNAS 105 (28), 9471-9476.

Nelson, E., Mendoza, G., Regetz, J., Polasky, S., Tallis, H., Cameron, D.R., Chan, K.M.A., Daily, G.C., Goldstein, J., Kareiva, P.M., Lonsdord, E., Naidoo, R., Ricketts, T.H., Shaw, M.R., 2009. Modeling multiple ecosystem services, biodiversity conservation, commodity production, and tradeoffs at landscape scales. Front. Ecol. Environ. 7 (1), 4-11.

Nieminen, M., 2003. Effects of clear-cutting and site preparation on water quality from a drained Scots pine mire in southern Finland. Boreal Environ. Res. 8, 53-59.

Nieminen, M., 2004. Export of dissolved organic carbon, nitrogen and phosphorus fol lowing clear-cutting of three Norway spruce forests growing on drained peatlands in southern Finland. Silva Fenn. 38, 123-132.

Nieminen, M., Ahti, E., Koivusalo, H., Mattsson, T., Sarkkola, S., Laurén, A., 2010. Export of suspended solids and dissolved elements from peatland areas after ditch network maintenance in south-central Finland. Silva Fenn. 44, 39-49.

Nieminen, M., Sallantaus, T., Ukonmaanaho, L., Nieminen, T.M., Sarkkola, S., 2017. Nitrogen and phosphorus concentrations in discharge from drained peatland forests are increasing. Sci. Total Environ. 609, 974-981.

Nykänen, H., Silvola, J., Alm, J., Martikainen, P., 1996. Fluxes of greenhouse gases CH4, $\mathrm{CO} 2$ and $\mathrm{N} 2 \mathrm{O}$ on some peat mining areas in Finland. In: Laiho, R., Laine, J., Vasander, H. (Eds.), Northern peatlands in global climatic change: Proceedings of the international workshop held in Hyytiälä, Finland, 8-12 October 1995. Publications of the Academy of Finland 1/96.

Ochoa, V., Urbina-Cardona, N., 2017. Tools for spatially modeling ecosystem services: publication trends, conceptual reflections and future challenges. Ecosyst. Serv. 26, 155-169.

Ojanen, P., Minkkinen, K., Alm, J., Penttilä, T., 2010. Soil-atmosphere CO2, CH4 and N2O fluxes in boreal forestry-drained peatlands. For. Ecol. Manage. 260, 411-421.

Ojanen, P., Minkkinen, K., Penttilä, T., 2013. The current greenhouse gas impact of forestry-drained boreal peatlands. For. Ecol. Manage. 289, 201-208.

Olander, L., Polasky, S., Kagan, J., Johnston, R., Wainger, L., Saah, D., Maguire, L., Boyd, J., Yoskowitz, D., 2017. So you want your research to be relevant? Building the bridge between ecosystem services research and practice. Ecosyst. Serv. 26, 170-182.

Onkila, H., Marttunen, M., Dufva, M., Nurmi, T., Hjerppe T., 2012. Turvetuotantoon soveltuvien soiden vesistövaikutusriskin arviointi Keski-Suomessa. Finnish Environment Institute. Available at: https://www.keskisuomi.fi/filebank/22693. TURVE_MCDA_raportti_25_04_2012.pdf. (Accessed 29.8.2018).

Päivänen, J., Hånell, B., 2012. In: Peatland Ecology and Forestry - a Sound Approach. University of Helsinki Department of Forest Sciences Publications, Helsinki, Finland, pp. 1-267.

Palviainen, M., Finér, L., Laurén, A., Mattsson, T., Högbom, L., 2015. A method to estimate the impact of clear-cutting on nutrient concentrations in boreal headwater streams. Ambio 44, 521-531.

Pennington, D.N., Dalzell, B., Nelson, E., Mulla, D., Taff, S., Hawthorne, P., Polasky, S. 2017. Cost-effective land use planning: optimizing land use and land management patterns to maximize social benefits. Ecol. Econ. 139, 75-90.

Pirinen, P., Simola, H., Aalto, J., Kaukoranta, J-P., Karlsson, P., Ruuhela, R., 2012 Tilastoja Suomen ilmastosta 1981-2010 (Climatological statistics of Finland 1981-2010). Ilmatieteen laitoksen raportteja 2012:1, Ilmatieteen laitos, Helsinki, Finland. Available at: https://helda.helsinki.fi/bitstream/handle/10138/35880/ Tilastoja_Suomen_ilmastosta_1981_2010.pdf? sequence = 4. (Accessed 31.8.2018)

Polasky, S., Nelson, E., Camm, J., Csuti, J., Fackler, P., Lonsdorf, E., Montgomery, C., White, D., Arthur, J., Garber-Yonts, B., Haight, R., Kagan, J., Starfield, A., Tobalske, C., 2008. Where to put things? Spatial land management to sustain biodiversity and economic returns. Biol. Conserv. 141, 1505-1524.

Polasky, S., Nelson, E., Pennington, D., Johnson, K.A., 2011. The impact of land-use change on ecosystem services, biodiversity and returns to landowners: a case study in the state of Minnesota. Environ. Resour. Econ. 48, 219-242.

Potschin, M.B., Haines-Young, R.H., 2011. Ecosystem services: exploring a geographical perspective. Prog. Phys. Geogr. 35, 575-594.

Pöyry, 2012. Turvetuotantoalueiden vesistökuormituksen arviointi - Vedenlaatu- ja kuormitustarkastelu vuosien 2003-2011 tarkkailuaineistojen perusteella. Pöyry Oy. p. 65 .

Rall, E.L., Kabisch, N., Hansen, R., 2015. A comparative exploration of uptake and potential application of ecosystem services in urban planning. Ecosys. Serv. 16, 230-242.

Rassi, P., Hyvärinen, E., Juslén, A., Mannerkoski, I. (Eds.), 2010. The 2010 Red List of Finnish Species. Ministry of Environment, Helsinki, Finland, pp. 685.

Redsven, V., Hirvelä, H., Härkönen, K., Salminen, O., Siitonen, M., 2013. MELA2012 Reference Manual, second ed. The Finnish Forest Research Institute, Vantaa, Finland, pp. 666.

Regina, K., Nykänen, H., Silvola, J., Martikainen, P., 1996. Fluxes of nitrous oxide from boreal peatlands as affected by peatland type, water table level and nitrification capacity. Biogeochemistry 35, 401-418.

Rosenthal, A., Verutes, G., Mckenzie, E., Arkema, K.K., Bhagabati, N., Bremer, I.I., Olwero, N., Vogl, A.L., 2014. Process matters: a framework for conducting decisionrelevant assessment of ecosystem services. Int. J. Biodivers. Sci. Ecosyst. Serv. Manage. 1-5.

Salm, J., Maddison, M., Tammik, S., Soosaar, K., Truu, J., Mander, Ü., 2012. Emissions of $\mathrm{CO}_{2}, \mathrm{CH}_{4}$ and $\mathrm{N}_{2} \mathrm{O}$ from undisturbed, drained and mined peatlands in Estonia. Hydrobiologia 692, 41-55.

Schindler, D.W., 1998. Sustaining aquatic ecosystems in boreal regions. Conservation Ecol. 2 (2), 18.

Schröter, M., Remme, R.P., Sumarga, E., Barton, D.N., Hein, L., 2015. Lessons learned for spatial modelling of ecosystem services in support of ecosystem accounting. Ecosyst. Serv. 13, 64-69.

Seppelt, R., Lautenbach, S., Folk, M., 2013. Identifying trade-offs between ecosystem services, land use, and biodiversity: a plea for combining scenario analysis and optimization on different spatial scales. Curr. Opin. Environ. Sustain. 5, 458-463.

Sherrouse, B.C., Semmens, D., Ancona, Z., Brunner, N., 2017. Analyzing land-use change scenarios for trade-offs among cultural ecosystem services in the Southern Rocky Mountains. Ecosyst. Serv. 26 (Part B), 431-444.

Shoyama, K., Kamiyama, C., Morimoto, J., Ooba, M., Okuro, T., 2017. A review of modelling approaches for ecosystem service assessment in the Asian region. Ecosyst. Serv. 26 (Part B), 316-328.

Shurpali, N., Hyvönen, N., Huttunen, J., Biasi, C., Nykänen, H., Pekkarinen, N., Martikainen, P., 2008. Bare soil and reed canary grass ecosystem respiration in peat extraction sites in Eastern Finland. Tellus 60B, 200-209.

Sun, C., Zhen, L., Giashuddin Miah, M., 2017. Comparison of ecosystem services provided by China's Poyang Lake wetland and Bangladesh's Tanguar Haor wetland. Ecosyst. Serv. 26 (Part B), 411-421.

Statistics Finland, 2018. Energy prices. 001 - Consumer Prices of Domestic Fuels in Energy Production (VAT not included). Available at: http://pxnet2.stat.fi/PXWeb/ pxweb/en/StatFin/StatFin_ene_ehi/statfin_ehi_pxt_001_fi.px/?rxid=49dcdfcf-4a194e7b-a41b-688929cbf32e. (Accessed 10.4.2018).

Sundh, I., Nilsson, M., Mikkelä, C., Granberg, G., Svensson, B.H., 2000. Fluxes of Methane and Carbon Dioxide on peat-mining Areas in Sweden. Ambio 29 (8), 499-503.

Tammi, I., Mustajärvi, K., Rasinmäki, J., 2017. Integrating spatial valuation of ecosystem services into regional planning and development. Ecosyst. Serv. 26, 329-344.

Tolvanen, A., Juutinen, A., Svento, R., 2013. Preferences of local people for the use of peatlands: the case of peatland-richest region in Finland. Ecol. Soc. 18 (2), 19.

Triviño, M., Juutinen, A., Mazziotta, A., Miettinen, K., Podkopaev, D., Reunanen, P., Mönkkönen, M., 2015. Identifying forest management regimes for optimizing both timber production and carbon in a boreal landscape. Ecosyst. Serv. 14, 179-189.

Trodahl, M.I., Jackson, B., Deslippe, J., Metherell, A., 2017. Investigating trade-offs between water quality and agricultural productivity using the Land Utilization and Capability Indicator(LUCI) - A New Zealand application. Ecosyst. Serv. 26 (Part B), 388-399.

Turkelboom, F., Leone, M., Jacobs, S., Kelemen, E., Carcia-Llorente, M., Baro, F., Termensen, M., Barton, D., Berry, P., Stange, E., Thoonen, M., Kalockai, A., Vadineanu, A., Castro, A., Czucz, B., Röckmann, C., Wurbs, D., Odee, D., Preda, E., Gomez-Baggethun, E., Rusch, G., Pastur, G., Palomo, I., Dick, J., Casaer, J., van Dick, J., Priess, J., Langemeyer, J., Mustajoki, J., Kotteroinen, L., Baptist, M., Peri, P., Mukhopadhyay, R., Aszalos, R., Roy, S.B., Luque, S., Rusch, V., 2018. When we cannot have it all: ecosystem service trade-offs in the context of spatial planning. Ecosys. Serv. 29, 566-578.

Väisänen, S., Silvan, N., Ihalainen, A., Soukka, R., 2013. Peat production in high-emission level peatlands - key to reduce climatic impacts? Energy Environ. 24 (5), 757-778.

Williamson, C.E., Overholt, E.P., Pilla, R.M., Leach, T.H., Brentrup, J.A., Knoll, L.B., Mette, E.M., Moeller, R.E., 2015. Ecological consequences of long-term browning in lakes. Sci. Rep. 5. https://doi.org/10.1038/srep18666.

World Energy Council, 2013. World Energy Resources, Chapter 6: Peat. 23rd ed. London, UK.

Zedler, J.B., Kercher, S., 2005. Wetland resources: status, trends, ecosystem services, and restorability. Annu. Rev. Environ. Resour. 30, 39-74.

Ympäristöministeriö, 2015. Suot ja Turvemaat maakuntakaavoituksessa. Suomen ympäristö 7. Ympäristöministeriö. Available at: https://helda.helsinki.fi/bitstream/ handle/10138/156305/SY_7_2015.pdf? sequence =1. (Accessed 29.8.2018). 